\title{
Leucine Oxidation and Protein Turnover in Clofibrate-induced Muscle Protein Degradation in Rats
}

\author{
Harbhajax S. Paul and Siamak A. Adibi, Gastrointestinal and Nutrition Unit, \\ Montefiore Hospital, University of Pittsburgh School of Medicine, Pittsburgh, \\ Pennsylvania 1.5213
}

\begin{abstract}
A B S T RACT Treatment of hyperlipidemia with clofibrate may result in development of a muscular syndrome. Our previous investigation (1979. J. Clin. Invest. 64: 405.) showed that chronic administration of clofibrate to rats causes myotonia and decreases glucose and fatty acid oxidation and total protein of skeletal muscle. In the present experiments we have investigated amino acid and protein metabolism in these rats. Clofibrate administration decreased the concentration of all three branched-chain amino acids without affecting those of others in muscle. Studies to examine the mechanism of decreases in muscle concentrations of branched-chain amino acids showed the following: (a) Plasma concentration of leucine was decreased, whereas there was no significant change in the concentration of isoleucine and valine. (b) Liver concentrations of all three branched-chain amino acids remained unaltered. (c) The uptake of cycloleucine (a nonmetabolizable analogue of leucine) by both muscle and liver was unaffected. $(d)$ The percentage of a trace amount of injected $\left[1-{ }^{14} \mathrm{C}\right]$ leucine expired as ${ }^{14} \mathrm{CO}_{2}$ in $1 \mathrm{~h}$ was significantly increased. (e) The capacity of muscle homogenate for $\alpha$-decarboxylation of leucine was enhanced, whereas that of liver was unaffected. (f) The activity of leucine transaminase was unaffected, whereas that of $\alpha$-ketoisocaproate dehydrogenase was increased in muscle.
\end{abstract}

Studies of protein synthesis, carried out as incorporation of leucine into protein and corrected for differences in specific activity, showed no alteration in liver but enhanced synthesis in muscle of clofibrate-fed rats. Clofibrate stimulated muscle protein degradation, which was demonstrated by increased tyrosine release from gastrocnemius muscle slices and by increased urinary excretion of 3-methylhistidine.

This work was presented at the Annual Meeting of the Federation of American Societies for Experimental Biology, in Atlantic City, N. J. 1978. Fed. Proc. 37: 541. (Abstr.)

Received for publication 20 November 1.978 and in revised form 14 February 1980 .
We conclude that (a) clofibrate treatment increased branched-chain amino acid oxidation by increasing the activity of branched-chain $\alpha$-ketoacid dehydrogenase in the muscle, $(b)$ increased oxidation results in selective decreases in the concentration of these amino acids in muscle, and $(c)$ decreases in branched-chain amino acid concentration may be responsible for increased protein degradation in muscle.

\section{INTRODUCTION}

Oxidation is an important pathway for the metabolism of branched-chain amino acids. Patients with hereditary disorders such as maple syrup urine disease and isovaleric acidemia, in which the oxidation of these amino acids is impaired, often have life-threatening metabolic derangements (1). Unlike other amino acids, which are oxidized mostly in the liver, the oxidation of branched-chain amino acids is accomplished principally in the skeletal muscle (2-5).

In 1971 Adibi and co-workers (6) reported that starvation increases oxidation of leucine by the skeletal muscle. This observation, which has also been noted by others $(7$; review), raised the possibility of alteration of branched-chain amino acid oxidation by nutritional and metabolic factors. Indeed, studies in a number of laboratories including our own have identified such factors. For example, ketone bodies (8), carnitine (9$11)$, hexanoate, and octanoate $(12,13)$ stimulate, and pyruvate (12) and decanoate (13) inhibit the oxidation of leucine by the muscle in vitro.

The fact that starvation and diabetes increase the oxidation of both fatty acids $(5,14)$ and branched-chain amino acids $(5,8,15,16)$ by the muscle, suggests that there may be a common modulation for oxidation of both substrates. To examine the existence of such a possibility, it would be important to investigate branchedchain amino acid oxidation by muscle in a situation of impaired fatty acid oxidation by this tissue. We have recently reported that treatment of rats with clofibrate decreases fatty acid oxidation by the skeletal muscle 
(17). Therefore, the clofibrate-fed rat provided us with a suitable animal model in which to test whether the oxidation of both substrates follows a similar pattern. In the present studies we examined the effects of clofibrate treatment on concentration, transport, transamination, and in vitro and in vivo oxidation of leucine.

As shown in our previous paper (17), clofibrate treatment decreases total protein of the skeletal muscle. In view of recent suggestions that branched-chain amino acids, particularly leucine, are possible regulators of protein turnover in the muscle $(18,19)$, the studies of leucine metabolism, described above, were accompanied by studies of protein synthesis and degradation in the muscle.

\section{METHODS}

Treatment of animals. Male Sprague-Dawley rats were housed in individual cages in air-conditioned quarters $\left(\sim 24^{\circ} \mathrm{C}\right)$ and received Purina Laboratory Chow (Ralston Purina Co., St. Louis, Mo.) and drinking water ad libitum. Clofibrate-treated rats received $30 \mathrm{mg}$ clofibrate (Atromid $\mathrm{S}$, Ayerst Laboratories, New York) per $100 \mathrm{~g}$ body wt daily for 2 wk. Additional details concerning the treatment are described in our previous publication (17).

Incorporation of leucine into tissue protein in vivo and determination of leucine specific activity. Control and clofibrate-fed rats were injected in the tail vein with $5 \mu \mathrm{Ci}$ of $\mathrm{L}-\left[1-{ }^{14} \mathrm{C}\right]$ leucine $/ 100 \mathrm{~g}$ body wt. After 5,10 , and $15 \mathrm{~min}$ the rats were sacrificed by stunning and decapitation, and blood samples were collected in chilled heparinized tubes. Immediately after blood collection, small portions of liver and gastrocnemius muscle were removed in duplicate and freezeclamped in liquid nitrogen.

For studies of leucine incorporation into protein, the frozen tissues were homogenized $(1: 9, \mathrm{wt} / \mathrm{vol})$ in cold $10 \%$ trichloroacetic acid, which also contained $10 \mathrm{mM}$ L-leucine. The homogenate was centrifuged for $10 \mathrm{~min}$ at $1,000 \mathrm{~g}$ and the resulting pellet was washed with $5 \mathrm{ml}$ of cold $10 \%$ trichloroacetic acid that contained $10 \mathrm{mM}$ L-leucine. The washed pellet was solubilized in $2 \mathrm{ml}$ of $0.3 \mathrm{M} \mathrm{NaOH}$ by heating for $20 \mathrm{~min}$ at $80^{\circ} \mathrm{C}$. The protein in a $0.2-\mathrm{ml}$ aliquot was reprecipitated by the addition of $2 \mathrm{ml}$ of $10 \%$ trichloroacetic acid. The precipitate was collected on a disk of Whatman filter paper No. 1 (Whatman Inc., Clifton, N. J.), which was uniformly covered with a layer of celite, and washed successively with $5 \%$ trichloroacetic acid, ethanol, and ether. This method of collecting and washing the protein sample has been validated (20). The celite cake containing the trapped protein was transferred to a scintillation counting vial and the protein dissolved by the addition of $0.5 \mathrm{ml}$ of Soluene-350 (New England Nuclear, Boston, Mass.). The radioactivity in each vial was determined in a liquid scintillation spectrometer (Packard Instrument Co., Inc., Downers Grove, Ill.) after addition of $10 \mathrm{ml}$ of Liquifluor (New England Nuclear) -toluene scintillation mixture to each vial. The incorporation of leucine into protein was expressed as disintegrations per minute per milligram of protein.

For determination of leucine specific activity, the frozen tissues were homogenized in $6 \%$ sulfosalicylic acid $(1 \mathrm{ml} / 100$ $\mathrm{mg}$ tissue). Blood samples were centrifuged for $10 \mathrm{~min}$ at $600 \mathrm{~g}$ to separate plasma, which was deproteinized with $6 \%$ sulfosalicylic acid (1:1 vol/vol). The sulfosalicylic acid extracts of tissues and plasma were analyzed for specific activity of leucine by a combination of ion-exchange chroma- tography (Beckman Instruments Inc., Spinco Div., model $120 \mathrm{C}$, Palo Alto, Calif.) and liquid scintillation spectrometry. The concentration of leucine was determined by the reported method (21). For the determination of radioactive leucine concentration, an aliquot $(1 \mathrm{ml})$ of sulfosalicylic acid extract was applied to a $0.9 \times 60-\mathrm{cm}$ ion-exchange column of UR-30 resin (Beckman Instruments, Inc.). The column was eluted with $0.2 \mathrm{~N}$ sodium citrate buffer, $\mathrm{pH} 3.20$, for $170 \mathrm{~min}$ followed

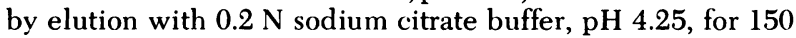
min. Under these elution conditions, leucine emerged from the column between 220 and $250 \mathrm{~min}$. Therefore, fractions were collected every minute during this period to ensure complete recovery of leucine. Fractions were collected directly into counting vials and after adding $10 \mathrm{ml}$ of Aquasol-2 (New England Nuclear), radioactivity was determined in a liquid scintillation spectrometer. Each sample was corrected for efficiency by external standardization and for background counts. Net counts in all fractions were pooled and the results were expressed as disintegrations per minute per nanomole of leucine.

The intracellular specific activity of leucine in muscle and liver was calculated by correcting for the concentration and specific activity of leucine in the extracellular space. The concentration and specific activity of leucine in the extracellular space was considered to be the same as that in plasma. Extracellular space in liver and gastrocnemius muscle was determined using inulin as described (22). The extracellular space in liver or muscle of clofibrate-fed rats did not differ significantly from that in the control rats. The extracellular space in livers of control and clofibrate-treated rats was $28.1 \pm 1.2$ and $26.3 \pm 1.1 \%$, respectively (mean \pm SEM in four rats). The extracellular space in muscle of control and clofibrate-treated rats was $14.5 \pm 0.6$ and $15.4 \pm 0.9 \%$, respectively (mean $\pm \mathrm{SEM}$ in four rats).

Determination of urinary constituents. Rat urine was collected daily from control and clofibrate-fed rats for the entire duration of clofibrate treatment $(2 \mathrm{wk})$. Total nitrogen in the urine was determined by the modified micro-Kjeldahl procedure using mercury as a catalyst (23). Urinary creatinine was determined by the picric acid method (24). For analysis of 3-methylhistidine concentration, an aliquot of the pooled urine sample was hydrolyzed with $\mathrm{HCl}$ to deacetylate any $\mathrm{N}$ acetyl-3-methylhistidine as outlined by Young et al. $(25,26)$. The 3-methylhistidine concentration was determined using an amino acid analyzer.

Muscle protein degradation in vitro. The method of Fulks et al. (18) for determining protein degradation in rat diaphragm was modified for the present study. Protein degradation was determined by measuring the release of tyrosine from gastrocnemius muscle slices instead of diaphragm. Gastrocnemius muscle slices weighing $\sim 100 \mathrm{mg}$ and $0.5 \mathrm{~mm}$ thick were prepared with a Stadie-Riggs microtome. Muscle slices were placed in flasks containing $3 \mathrm{ml}$ of Krebs-Ringer bicarbonate buffer (27), $\mathrm{pH} 7.4$, containing $10 \mathrm{mM}$ glucose and saturated with $95 \% \quad \mathrm{O}_{2}-5 \% \quad \mathrm{CO}_{2}$. After preincubating the stoppered flasks for $30 \mathrm{~min}$ at $37^{\circ} \mathrm{C}$, the muscle slices were transferred to flasks containing $3 \mathrm{ml}$ of Krebs-Ringer bicarbonate buffer that contained $0.5 \mathrm{mM}$ cycloheximide and incubated at $37^{\circ} \mathrm{C}$. Preliminary experiments were carried out to establish the linearity of tyrosine release from the gastrocnemius muscle slices. The release of tyrosine was linear for up to $3 \mathrm{~h}$. The amount ( $\mathrm{nmol} / \mathrm{mg}$ muscle) of tyrosine released was $0.27 \pm 0.01,0.50 \pm 0.01$, and $0.72 \pm 0.03$ in 1,2 , and $3 \mathrm{~h}$, respectively (mean $\pm S E M$, in seven to eight rats). Therefore, in all subsequent studies tyrosine release was determined in muscle slices incubated for $2 \mathrm{~h}$. At the end of $2 \mathrm{~h}$ of incubation, a $2-\mathrm{ml}$ aliquot of the medium was combined with $0.5 \mathrm{ml}$ of cold $50 \%$ trichloroacetic acid, mixed, and centrifuged. The 
muscle slices were blotted and homogenized in $2 \mathrm{ml}$ of cold $10 \%$ trichloroacetic acid and centrifuged. The acid soluble fractions of the medium and muscle homogenate were assayed for tyrosine according to the fluorometric method of Waalkes and Udenfriend (28).

Amino acid concentration in tissues and plasma. The amino acid analyses were accomplished by ion-exchange chromatography using an amino acid analyzer as reported (21). Tissues and plasma were prepared for amino acid analysis as described above for specific activity studies.

Cycloleucine uptake by tissues in vivo. The transport of the nonmetabolizable amino acid cycloleucine into liver and gastrocnemius muscle was measured by the tissue accumulation method as reported (22). The accumulation of cycloleucine within the tissues was expressed as distribution ratio (intracellular concentration/extracellular concentration) and was calculated by the described formulae (22).

Leucine oxidation in vivo. Control and clofibrate-fed rats were injected in the tail vein with $2 \mu \mathrm{Ci}$ of $\mathrm{L}-\left[1-{ }^{14} \mathrm{C}\right]$ leucine/ $100 \mathrm{~g}$ body wt. Immediately after the injection, each animal was placed in a metabolic cage (Plas-Labs, Lansing, Mich.) for a period of $1 \mathrm{~h}$ and the expired ${ }^{14} \mathrm{CO}_{2}$ was trapped in $5 \mathrm{ml}$ of hydroxide of Hyamine-10X (Rohm \& Haas Co., Philadelphia, Penn.) for 12 successive 5-min intervals. A $1-\mathrm{ml}$ aliquot of the trapping solution was transferred to a scintillation counting vial containing $10 \mathrm{ml}$ of Liquifluor-toluene scintillation counting mixture. The radioactivity in each vial was determined in a liquid scintillation spectrometer. Radioactivity in the expired $\mathrm{CO}_{2}$ was expressed as a percentage of the injected dose expired as ${ }^{14} \mathrm{CO}_{2}$.

Leucine oxidation in vitro. The rate of leucine oxidation was investigated by measuring the rate of ${ }^{14} \mathrm{CO}_{2}$ production when $\mathrm{L}-\left[1{ }^{14} \mathrm{C}\right]$ leucine was incubated with tissue homogenates as reported (8). Briefly, the studies were carried out in $5 \mathrm{ml}$ of described incubation medium (8) containing $1 \mu \mathrm{mol} \mathrm{L}$ -

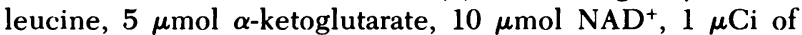

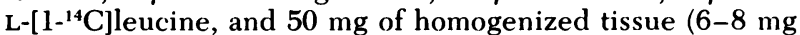
protein), and incubated at $37^{\circ} \mathrm{C}$ for $60 \mathrm{~min}$.

Leucine transaminase activity. Leucine transaminase activity was determined by measuring the rate of formation of $\alpha$-ketoisocaproate when $\mathrm{L}-\left[1-{ }^{14} \mathrm{C}\right]$ leucine was incubated with tissue homogenates as reported previously $(8,29)$. Briefly, the studies were carried out in $1 \mathrm{ml}$ reaction mixture that contained $15 \mu \mathrm{mol}$ leucine, $15 \mu \mathrm{mol} \alpha$-ketoglutarate, $1 \mu \mathrm{mol}$ pyridoxal phosphate, $25 \mu \mathrm{mol}$ sodium pyrophosphate, $\mathrm{pH} 8.6$, $1 \mu \mathrm{Ci} \mathrm{L}-\left[1-{ }^{14} \mathrm{C}\right]$ leucine, and $100 \mathrm{mg}$ homogenized tissue $(12-$ $15 \mathrm{mg}$ protein), and incubated at $37^{\circ} \mathrm{C}$ for $6 \mathrm{~min}$ for muscle and $30 \mathrm{~min}$ for liver. $\alpha$-Ketoisocaproate was separated from leucine by ion-exchange chromatography as reported (29).

$\alpha$-Ketoisocaproate dehydrogenase activity. $\alpha$-Ketoisocaproate dehydrogenase activity was determined by measuring the rate of ${ }^{14} \mathrm{CO}_{2}$ production when $\left[\alpha-1-{ }^{14} \mathrm{C}\right]$ ketoisocaproate was incubated with muscle homogenates. Incubation studies were carried out with methods similar to those described for leucine oxidation with the exception that 1 $\mu \mathrm{mol}$ of $\alpha$-ketoisocaproate and $1 \mu \mathrm{Ci}$ of $\left[\alpha-1-{ }^{14} \mathrm{C}\right]$ ketoisocaproate were substituted for labeled and unlabeled leucine in the reaction mixture.

Determination of protein. Protein concentration in the tissue homogenates was measured by the method of Lowry et al. (30) using bovine serum albumin as the standard.

Materials. $\quad \mathrm{L}-\left[1-{ }^{14} \mathrm{C}\right]$ Leucine $(56.90 \mathrm{mCi} / \mathrm{mmol})$ was purchased from New England Nuclear. $\left[\alpha-1-{ }^{14} \mathrm{C}\right]$ Ketoisocaproate was prepared in this laboratory from $\mathrm{L}-\left[1-{ }^{14} \mathrm{C}\right]$ leucine by incubation with L-amino acid oxidase (Boehringer Mannheim Biochemicals, Indianapolis, Ind.) as described by Rudiger et al. (31). About $90 \%$ of the labeled leucine was recovered as $\alpha$ ketoisocaproate. The purity of the product was assessed by thin-layer chromatography using a solvent system of tertbutanol/methyl ethyl ketone/water/formic acid in proportions of 20:20:5:0.12 by volume (32). All of the radioactivity was present at one spot, which corresponded to $\alpha$-ketoisocaproate. All other chemicals used were of the reagent grade.

Statistics. The $t$ test was used for the statistical analysis of the data (33).

\section{RESULTS}

As described in our previous paper (17), there was no significant difference between the initial body weight or weight gain of control and clofibrate-fed rats during the $2 \mathrm{wk}$ of treatment. Among the various effects of clofibrate on tissue composition, detailed earlier (17), there was an increase in the protein concentration in the liver and a decrease in protein concentration in the muscle. The following studies were performed to provide insight into the mechanism of these effects.

Protein synthesis in vivo. The rate of incorporation of $\left[{ }^{14} \mathrm{C}\right]$ leucine into tissue protein was used as an index of protein synthesis. Clofibrate treatment had no significant effect on rates of incorporation of $\left[{ }^{14} \mathrm{C}\right]$ leucine into protein of gastrocnemius muscle (Table I). These rates, however, were reduced in the liver of clofibratetreated rats (Table I). The rate of incorporation of a ${ }^{14} \mathrm{C}$-labeled amino acid into tissue proteins could be affected by a change in specific activity. We, therefore, measured the specific activity of leucine in plasma and intracellular fluid of liver and gastrocnemius muscle of control and clofibrate-treated rats.

As shown in Table I, there was no significant difference between the specific activity of leucine measured either in plasma, muscle, or liver of control and clofibrate-fed rats $5 \mathrm{~min}$ after the isotope injection. However, at both 10- and 15-min intervals the specific activities of leucine were generally lower in clofibratetreated rats. It should be noted that specific activities of leucine, whether in control or clofibrate-fed rats, were always several fold greater in the muscle than in the liver (Table I). Furthermore, the decrease in specific activity with time was more rapid in plasma and tissues of clofibrate-fed than in control rats. When the rates of incorporation of leucine into tissue protein were corrected for differences in specific activity, there was no longer any significant difference between rates of leucine incorporation in the liver of the two groups of rats, but the rates of $\left[{ }^{14} \mathrm{C}\right]$ leucine incorporation into protein became significantly greater in the muscle of clofibrate-fed rats (Table I).

Muscle protein degradation in vitro. The amino acid tyrosine is neither synthesized nor degraded by the muscle (34). Therefore, the release of tyrosine has been used as an index of muscle protein breakdown (18). To permit the measurement of protein degradation independently of protein synthesis, cycloheximide was added to the incubation medium to block protein 
TABLE I

Effect of Clofibrate on Specific Activity of Leucine and on Rate of Leucine Incorporation into Proteins

\begin{tabular}{|c|c|c|c|c|c|c|}
\hline \multirow[b]{3}{*}{ Tissue } & \multirow[b]{3}{*}{ Time } & & & \multicolumn{3}{|c|}{ Rate of leucine incorporation } \\
\hline & & \multicolumn{2}{|c|}{ Specific activity } & \multirow[b]{2}{*}{ Control } & \multicolumn{2}{|c|}{ Clofibrate-fed } \\
\hline & & Control & Clofibrate-fed & & Uncorrected & Corrected \\
\hline & $\min$ & \multicolumn{2}{|c|}{$d p m / n m o l$} & \multicolumn{3}{|c|}{$d p m / m g$ protein } \\
\hline \multirow{3}{*}{$\begin{array}{l}\text { Gastrocnemius } \\
\text { muscle }\end{array}$} & 5 & $330 \pm 43$ & $393 \pm 35$ & $141 \pm 14$ & $161 \pm 29$ & $192 \pm 34$ \\
\hline & 10 & $271 \pm 37$ & $156 \pm 12 *$ & $206 \pm 20$ & $230 \pm 22$ & $399 \pm 38 \S$ \\
\hline & 15 & $141 \pm 8$ & $65 \pm 7 \S$ & $260 \pm 8$ & $287 \pm 13$ & $623 \pm 29 \S$ \\
\hline \multirow[t]{3}{*}{ Liver } & 5 & $132 \pm 21$ & $79 \pm 7$ & $685 \pm 101$ & $405 \pm 73$ & $677 \pm 122$ \\
\hline & 10 & $59 \pm 7$ & $32 \pm 9$ & $1,246 \pm 128$ & $649 \pm 58 \S$ & $1,198 \pm 106$ \\
\hline & 15 & $37 \pm 4$ & $17 \pm 2 \S$ & $1,491 \pm 50$ & $758 \pm 51 \S$ & $1,650 \pm 111$ \\
\hline \multirow[t]{3}{*}{ Plasma } & 5 & $395 \pm 6$ & $429 \pm 18$ & - & - & - \\
\hline & 10 & $225 \pm 12$ & $173 \pm 14^{*}$ & - & - & - \\
\hline & 15 & $149 \pm 17$ & $116 \pm 6$ & & & \\
\hline
\end{tabular}

Specific activity of leucine and rate of leucine incorporation into tissue proteins were determined following the injection of a trace amount of $\left[{ }^{14} \mathrm{C}-1\right]$ leucine to control and clofibrate-fed rats. The rate of leucine incorporation was corrected based on the differences in specific activity of leucine between control and clofibrate-fed rats. All values mean $\pm \mathrm{SEM}, n=4$ rats.

Significantly different from controls at:

$* P<0.05$.

$\S P<0.01$.

synthesis (18). As shown in Table II, in the presence of cycloheximide, the tyrosine release into the medium by gastrocnemius muscle slices was significantly higher $(32 \%)$ in clofibrate-fed than in control rats. The total amount of tyrosine released by the muscle slices, as assessed by accumulation of tyrosine in the medium together with changes in the tyrosine pool in muscle slices with time, was also significantly higher in clofibrate-fed than in control rats (Table II). The rate of tyrosine release by gastrocnemius muscle slices of control rats was not only linear for up to $3 \mathrm{~h}$ but was also comparable to the rate of tyrosine release by diaphragm (18) and soleus muscle (35) supporting the use of muscle slices for the study of muscle protein degradation in vitro.

TABLE II

Effect of Clofibrate on Tyrosine Release by the Gastrocnemius Muscle Slices

\begin{tabular}{|c|c|c|c|}
\hline Treatment & In medium & $\begin{array}{c}\text { Change in } \\
\text { muscle tyrosine } \\
\text { in } 2 \mathrm{~h}\end{array}$ & Total \\
\hline & \multicolumn{3}{|c|}{ nmol/mg muscle/2 h } \\
\hline Control & $0.50 \pm 0.02$ & $0.09 \pm 0.01$ & $0.59 \pm 0.01$ \\
\hline Clofibrate-fed & $0.66 \pm 0.05^{*}$ & $0.08 \pm 0.01$ & $0.74 \pm 0.06 *$ \\
\hline
\end{tabular}

All values mean $\pm \mathrm{SEM}, n=6$ rats.

* Significantly different from controls, $P<0.05$.
Muscle protein degradation in vivo. To investigate the physiological relevance of increased muscle protein degradation in vitro as shown above, we measured the urinary excretion of 3-methylhistidine in control and clofibrate-fed rats. This amino acid is formed by methylation of specific histidine residues of peptide chains and is largely confined to actin and myosin of skeletal muscle $(36,37)$. Unlike other amino acids, 3methylhistidine when released by degradation of muscle proteins is not reutilized for protein synthesis nor catabolized as an energy source, but is quantitatively excreted in the urine (25). Based on these considerations, the urinary excretion of 3-methylhistidine has been used as an index of muscle protein breakdown in vivo (26). As shown in Table III, the urinary excretion of 3-methylhistidine was significantly higher $(35 \%)$ in clofibrate-fed than in control rats. This increase in 3-methylhistidine excretion was not accompanied by any significant alteration in urinary excretion of either nitrogen or creatinine (Table III).

Amino acid concentration in tissues and plasma. To determine whether metabolism of branched-chain amino acids was indeed altered by chronic clofibrate administration, we measured the concentration of these amino acids along with several others in the liver, gastrocnemius muscle, and plasma (Table IV). Among the 14 individual amino acids measured, only the concentrations of branched-chain amino acids in the muscle were significantly altered by clofibrate treat- 
TABLE III

Effect of Clofibrate on Urinary Excretion of Metabolites and Muscle Protein Breakdown

\begin{tabular}{lcc}
\hline \multicolumn{1}{c}{ Measurement } & Control & Clofibrate-fed \\
\hline Urine volume, $m l / 2 w k$ & $152 \pm 13$ & $150 \pm 9$ \\
Urinary nitrogen, $g / 2 w k$ & $5.69 \pm 0.80$ & $5.24 \pm 1.29$ \\
Urinary creatinine, $m g / 2 w k$ & $212 \pm 33$ & $196 \pm 22$ \\
$\begin{array}{l}\text { Urinary 3-methylhistidine, } \\
\quad \mu m o l / 2 w k\end{array}$ & $42.59 \pm 2.39$ & $57.44 \pm 3.91^{*}$ \\
$\begin{array}{l}\text { Muscle protein breakdown, } \\
\text { g/2 } w k\end{array}$ & $11.06 \pm 0.62$ & $14.92 \pm 1.01^{*}$ \\
\hline
\end{tabular}

All values are mean $\pm \mathrm{SEM}, n=6$ rats.

* Significantly different from controls at $P<0.05$.

ment. In contrast, the concentrations of these amino acids in the liver of clofibrate-fed rats remained unaffected (Table IV). The concentration of leucine was reduced in plasma, whereas that of isoleucine and valine was not significantly affected (Table IV). Clofibrate treatment significantly reduced concentrations of alanine, threonine, and asparagine-glutamine in plasma and significantly increased concentrations of glutamate and phenylalanine in liver (Table IV).

Among the possible factors responsible for the above selective decreases in muscle concentration of branched-chain amino acids, alterations in tissue uptake and/or oxidation of these amino acids appeared more probable. The following studies were performed to provide insight into these aspects of branched-chain amino acid metabolism in clofibrate-treated rats.

Cycloleucine uptake in vivo. For studies of uptake, we investigated the accumulation of $\left[{ }^{14} \mathrm{C}\right]$ cycloleucine, a nonmetabolizable analogue of leucine, by gastrocnemius muscle and liver. Muscle and liver were singled out for these and the following studies because the metabolism of intravenously administered amino acids is principally accomplished in these tissues $(38,39)$. The uptake of cycloleucine in vivo, as measured by the distribution ratio was not significantly affected by clofibrate either in gastrocnemius muscle $(1.18 \pm 0.07$ in controls vs. $1.35 \pm 0.01$ in clofibrate-fed rats, mean $\pm \mathrm{SEM}$ in four rats) or in liver $(1.75 \pm 0.05$ in control vs. $1.70 \pm 0.11$ in clofibrate-fed rats, four rats)

Leucine oxidation in vivo. To investigate oxidation in vivo, we measured rates of ${ }^{14} \mathrm{CO}_{2}$ production after injection of a trace dose of $\left[1-{ }^{14} \mathrm{C}\right]$ leucine in intact rats. As shown in Fig. 1, clofibrate-fed rats expired significantly more ${ }^{14} \mathrm{CO}_{2}$ in comparison to control rats between 15- and 55-min intervals. The percentage of the injected dose expired as ${ }^{14} \mathrm{CO}_{2}$ during the initial l-h period was also significantly higher in clofibrate-fed than in control rats $(23.32 \pm 1.54$ vs. $13.62 \pm 1.20, P$ $<0.01)$. It should be noted that due to lower specific activities of leucine in tissues and plasma of clofibratefed than in control rats (Table I), the enhancement of leucine oxidation is probably greater than that apparent from the results of the present studies (Fig. 1).

Leucine oxidation in vitro. To determine whether

TABLE IV

Effect of Clofibrate on the Concentrations of Free Amino Acids in Tissues and Plasma

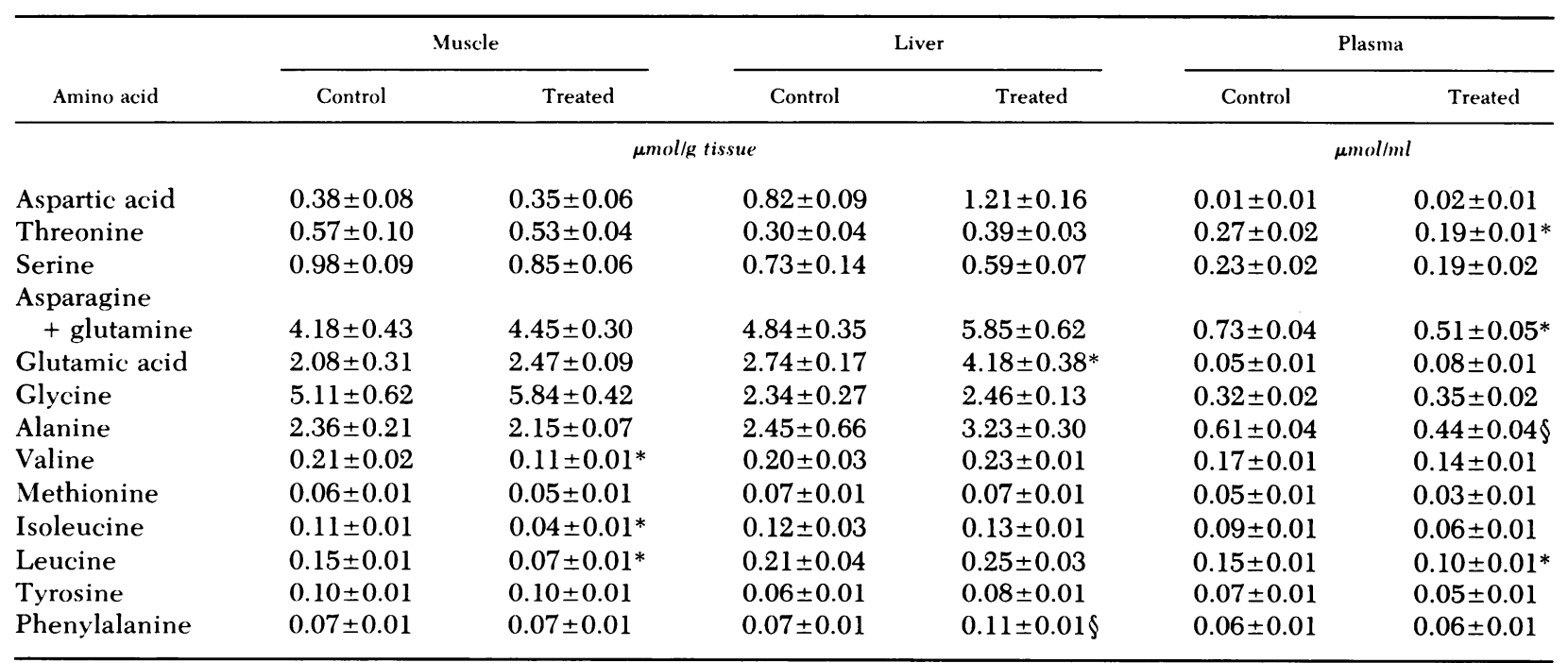

All values mean $\pm \mathrm{SEM}$ in five to seven rats.

Significantly different from controls at:

$* P<0.01$.

$\S P<0.05$. 


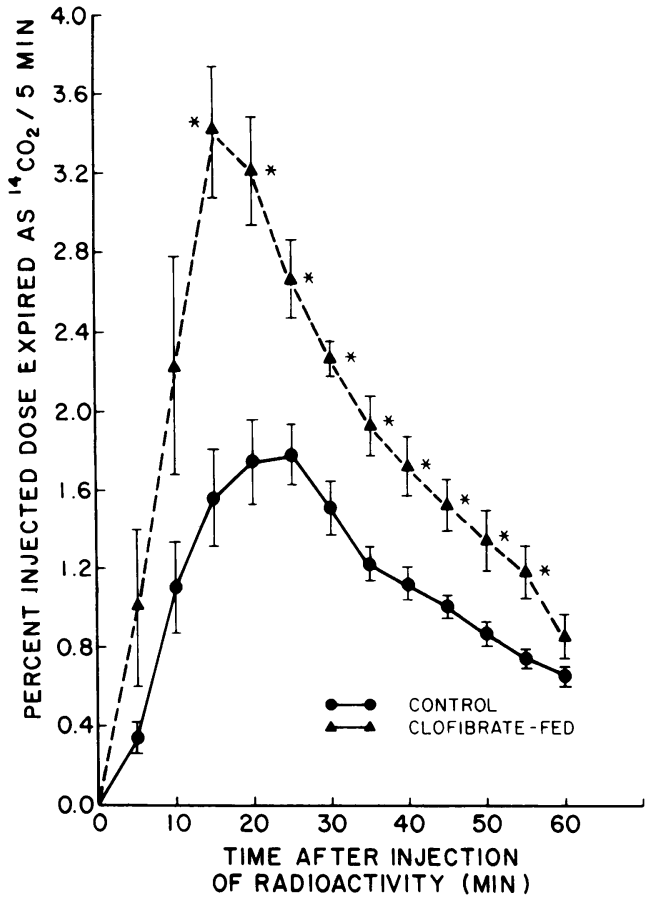

Figure 1 Rates (mean \pm SEM in five to six rats) of leucine oxidation in vivo in control and clofibrate-fed rats. Statistical significance for the difference between control and clofibratefed rats is shown as an asterisk, $P<0.01$.

an increase in leucine oxidation by muscle or liver or both accounted for the increased oxidation in vivo, we investigated the effect of clofibrate on the capacity of these tissues to oxidize leucine in vitro. As shown in Table $\mathrm{V}$, the rate of $\alpha$-decarboxylation of leucine by the gastrocnemius muscle homogenate was $48 \%$ higher in clofibrate-fed than in control rats. In contrast to muscle, the rate of leucine oxidation by the liver homogenate was not significantly affected by clofibrate treatment (Table V). It should be noted that the difference in oxidation was not due to any difference in concentration or specific activity of leucine in the incubation medium. The initial concentration and specific activity of leucine in the medium was identical for both groups of rats. The amounts of endogenous leucine provided by tissue homogenates were trivial $(3-8 \mathrm{nmol})$ as compared to the amount of leucine added.

Leucine transaminase and $\alpha$-ketoisocaproate dehydrogenase activities. Clofibrate-induced increases in the rate of $\alpha$-decarboxylation of leucine by the muscle homogenate could be caused by the effect of clofibrate on either leucine transaminase or decarboxylation of $\alpha$-ketoisocaproate (transamination product of leucine) or on both of these reactions. To investigate these possibilities, we determined the activity of leucine transaminase and $\alpha$-ketoisocaproate dehydrogenase by the muscle homogenate of control and clofibrate-fed rats. Since clofibrate did not affect leucine oxidation by the liver, this tissue was not included in this study. Clofibrate treatment did not affect the activity of leucine transaminase (Table V), but the treatment significantly increased the activity of $\alpha$-ketoisocaproate dehydrogenase in clofibrate-treated rats (Table V).

\section{DISCUSSION}

A striking finding of these experiments was that clofibrate administration to otherwise adequately fed rats decreased concentrations of branched-chain amino acids without affecting concentrations of other amino acids in the muscle (Table IV). Changes in muscle concentrations of amino acids in response to nutritional

TABLE V

Effect of Clofibrate on Leucine Oxidation, Leucine Transaminase, and $\alpha$-Ketoisocaproate Dehydrogenase

\begin{tabular}{|c|c|c|c|}
\hline Tissue & Measurement & Control & Clofibrate-fed \\
\hline Liver & $\begin{array}{l}\text { Leucine oxidation, } \\
\qquad \mathrm{mmol} / \mathrm{mg} \text { protein } / 60 \mathrm{~min}\end{array}$ & $1.32 \pm 0.08$ & $1.46 \pm 0.10$ \\
\hline $\begin{array}{l}\text { Gastrocnemius } \\
\text { muscle }\end{array}$ & $\begin{array}{l}\text { Leucine oxidation, } \\
\mathrm{nmol} / \mathrm{mg} \text { protein } / 60 \mathrm{~min}\end{array}$ & $1.52 \pm 0.06$ & $2.26 \pm 0.12 *$ \\
\hline $\begin{array}{l}\text { Gastrocnemius } \\
\text { muscle }\end{array}$ & $\begin{array}{l}\text { Leucine transaminase, } \\
n m o l / m g \text { protein } / \mathrm{min}\end{array}$ & $7.25 \pm 0.56$ & $7.57 \pm 0.32$ \\
\hline $\begin{array}{l}\text { Gastrocnemius } \\
\text { muscle }\end{array}$ & $\begin{array}{l}\alpha \text {-Ketoisocaproate dehydrogenase, } \\
n m o l / m g \text { protein } / 60 \mathrm{~min}\end{array}$ & $2.93 \pm 0.10$ & $4.47 \pm 0.19 *$ \\
\hline
\end{tabular}

Rates of leucine oxidation and activities of leucine transaminase and $\alpha$-ketoisocaproate dehydrogenase were determined in tissue homogenates of control and clofibrate-fed rats. All values mean $\pm S E M$ in $8-10$ rats.

* Significantly different from controls at $P<0.01$. 
and hormonal alterations are not limited to branchedchain amino acids but include others $(40,41)$. Four different mechanisms could conceivably account for the above decreases in concentrations of branched-chain amino acids. First, there could have been a decrease in the muscle uptake of circulating branched-chain amino acids. This possibility is dismissed by our observation that clofibrate treatment had no significant effect on muscle accumulation of cycloleucine. Second, there could have been increased muscle release of branched-chain amino acids to systemic circulation. This possibility is not supported by the observation that clofibrate treatment lacked significant effect on plasma concentration of either isoleucine or valine, and actually decreased that of leucine (Table IV). Third, there could have been increased incorporation and/or decreased production of branched-chain amino acids from muscle protein. This mechanism does not seem likely since neither altered protein synthesis nor degradation would affect concentrations of branchedchain amino acids alone without affecting those of others. In fact, clofibrate treatment actually increased degradation of muscle protein. Fourth, there could have been increased oxidation of branchedchain amino acids by the muscle. Among the various mechanisms discussed above, this last possibility is well supported by two sets of observations: (a) In comparison to control rats, clofibrate-fed rats displayed a greater rate of ${ }^{14} \mathrm{CO}_{2}$ production in the expired air after intravenous injection of a trace amount of $\left[{ }^{14} \mathrm{C}\right]$ leucine (Fig. 1). (b) Clofibrate treatment increased the capacity of skeletal muscle to oxidize leucine in vitro (Table V). Based on these considerations, we conclude that the decreases in branched-chain amino acid concentrations in the muscle are due to their increased oxidation in this tissue. This conclusion receives additional support from the observation that in the liver, where leucine oxidation was not altered (Table $\mathrm{V})$, there was also no significant change in the concentration of branched-chain amino acids (Table IV).

The results of our studies also show that between the two enzymes concerned with $\alpha$-decarboxylation of leucine by the muscle, the activity of $\alpha$-ketoisocaproate dehydrogenase is more sensitive to metabolic regulation than that of leucine transaminase. Our previous studies (17), together with the present data, indicate that the activity of $\alpha$-ketoisocaproate dehydrogenase in the muscle is not related to alteration of fatty acid oxidation in this tissue, in that activity of this enzyme is increased in conditions that either increase (starvation and diabetes) $(5,14)$ or decrease (clofibratetreatment) muscle oxidation of fatty acids (17). On the other hand, clofibrate treatment, like starvation and diabetes, results in increased fatty acid oxidation by the liver (17) and increased concentrations of ketone bodies in plasma and tissues (17). Our earlier studies have shown that ketone bodies, particularly acetoacetate, enhance the activity of $\alpha$-ketoisocaproate dehydrogenase in muscle (8). Therefore, the enhancement of fatty acid oxidation by the liver with consequent ketogenesis may account for the increased activity of $\alpha$-ketoisocaproate dehydrogenase in muscle of clofibrate-fed rats.

Protein concentration in the muscle is the result of an equilibrium between rates of synthesis and degradation. Clofibrate treatment appears to stimulate both of these rates (Tables I-III), but changes the equilibrium in favor of degradation. This view is consistent with our earlier observation that clofibrate treatment decreases the protein concentration in the muscle (17). Assuming that the rates of myofibrillar and sarcoplasmic protein breakdown are of approximately the same magnitude (42), and that the 3-methylhistidine content of rat skeletal muscle is $3.85 \mu \mathrm{mol} / \mathrm{g}$ protein (43), the rate of muscle protein degradation can be estimated from the urinary 3-methylhistidine excretion data. As shown in Table III, the amount of muscle protein degraded over the entire 2 -wk experiment was $35 \%$ higher in clofibrate-fed than in control rats.

Based on available evidence, at least two mechanisms can be considered for increased protein degradation in the muscle of clofibrate-fed rats. First, insulin has been shown to have an inhibitory effect on the degradation of muscle protein $(44,45)$. As reported by others (46) and confirmed by us (17), clofibrate treatment significantly reduced the levels of insulin in plasma and may have been responsible for the increased rate of muscle protein degradation. However, this explanation fails to take into account that insulin inhibits protein degradation in liver (47) and the liver protein content of clofibrate-fed rats was actually increased (17). Second, it has been proposed that branched-chain amino acids, particularly leucine, inhibit the breakdown of muscle protein $(18,19)$. As shown in Table IV, clolfibrate treatment selectively decreased the concentrations of all three branched-chain amino acids in the muscle.

These observations may also provide further insight into the pathogenesis of the muscular syndrome in patients who receive clofibrate therapy for treatment of hyperlipidemias $(48,49)$. Our previous electromyographic and electron microscopic studies revealed the development of myotonia and dilation of transverse tubules of skeletal muscle fibers of rats similarly treated with clofibrate (50). The transverse tubules, which are extensions of the surface membrane within the muscle fiber, have been implicated to play a key role in the genesis of electrical activity of the muscle (51) and have been shown to be affected in the muscle biopsies of patients with myotonia (52). Although we did not find any evidence of muscle damage with investigation by light microscopy (50), others have found extensive 
degeneration and necrosis of muscle fibers using a higher dose of clofibrate for a longer duration (53). Therefore, the alterations of protein and energy metabolism, together with the dilation of transverse tubules, are probably a subtle manifestation of the toxic effect of this drug on the skeletal muscle.

\section{ACKNOWLEDGMENT}

This investigation was supported by National Institute of Arthritis, Metabolism, and Digestive Diseases (grant AM15855).

\section{REFERENCES}

1. Dancis, J., and M. Levitz. 1978. Abnormalities of branchedchain amino acid metabolism. In The Metabolic Basis of Inherited Disease. J. B. Stanbury, J. B. Wyngaarden, and D. S. Fredrickson editors. McGraw-Hill Book Co., New York. 397-410.

2. Miller, L. L. 1962. The role of the liver and the nonhepatic tissues in the regulation of free amino acid levels in the blood. In Amino Acid Pools. J. T. Holden, editor. Elsevier North-Holland, Inc. New York. 708-721.

3. Odessey, R., and A. L. Goldberg. 1972. Oxidation of leucine by rat skeletal muscle. Am. J. Physiol. 223: 13761383.

4. Meikle, A. W., and G. J. Klain. 1972. Effect of fasting and fasting-refeeding on conversion of leucine into $\mathrm{CO}_{2}$ and lipids in rats. Am. J. Physiol. 222: 1246-1250.

5. Adibi, S. A., B. A. Krzysik, E. L. Morse, P. M. Amin, and E. R. Allen. 1974. Oxidative energy metabolism in the skeletal muscle: biochemical and ultrastructural evidence for adaptive changes. J. Lab. Clin. Med. 83: 548-562.

6. Adibi, S. A., E. Morse, and P. Amin. 1971. Adaptive changes in leucine metabolism: Alterations in pool size and oxidative degradation in tissues. Clin. Res. 19: 470. (Abstr.)

7. Adibi, S. A. 1976. Metabolism of branched-chain amino acids in altered nutrition. Metab. Clin. Exp. 25: 12871302.

8. Paul, H. S., and S. A. Adibi. 1978. Leucine oxidation in diabetes and starvation: effects of ketone bodies on branched-chain amino acid oxidation in vitro. Metab. Clin. Exp. 27: 185-200.

9. Paul, H. S., and S. A. Adibi. 1978. Effect of carnitine on branched-chain amino acid oxidation by liver and skeletal muscle. Am. J. Physiol. 234: E494-E499.

10. Bieber, L. L., and Y. R. Choi. 1977. Isolation and identification of aliphatic short-chain acylcarnitines from beef heart: possible role for carnitine in branched-chain amino acid metabolism. Proc. Natl. Acad. Sci. U. S. A. 74: 2795-2798.

11. Van Hinsbergh, V. W., J. H. Veerkamp, P. J. M. Engelen, and W. J. Ghijsen. 1978. Effect of L-carnitine on the oxidation of leucine and valine by rat skeletal muscle. Biochem. Med. 20: 115-124.

12. Buse, M. G., J. F. Biggers, K. H. Friderici, and J. F. Buse. 1972. Oxidation of branched-chain amino acids by isolated hearts and diaphragms of the rat.J. Biol. Chem. 247: 80858096.

13. Paul, H. S., and S. A. Adibi. 1976. Assessment of effect of starvation, glucose, fatty acids and hormones on $\alpha$-decarboxylation of leucine in skeletal muscle of rat. J. Nutr. 106: $1079-1088$.

14. Fritz, I. B., and E. Kaplan. 1960. Effects of glucose on fatty acid oxidation by diaphragms from normal and alloxan-diabetic fed and starved rats. Am. J. Physiol. 198: $39-44$.

15. Goldberg, A. L., and R. Odessey. 1972. Oxidation of amino acids by diaphragms from fed and fasted rats. Am.J. Physiol. 223: 1384-1391.

16. Buse, M. G., H. F. Herlong, and D. A. Weigand. 1976. The effect of diabetes, insulin, and the redox potential on leucine metabolism by isolated rat diaphragm. Endocrinology 98: 1166-1175.

17. Paul, H. S., and S. A. Adibi. 1979. Paradoxical effects of clofibrate on liver and muscle metabolism in rats: Induction of myotonia and alteration of fatty acid and glucose oxidation. J. Clin. Invest. 64: 405-412.

18. Fulks, R. M., J. B. Li, and A. L. Goldberg. 1975. Effects of insulin, glucose, and amino acids on protein turnover in rat diaphragm. J. Biol. Chem. 250: 290-298.

19. Buse, M. G., and S. S. Reid. 1975. Leucine a possible regulator of protein turnover in muscle. J. Clin. Invest. 56: $1250-1261$.

20. Mans, R. J., and G. D. Novelli. 1961. Measurement of the incorporation of radioactive amino acids into protein by a filter-paper disk method. Arch. Biochem. Biophys. 94: 48-53.

21. Adibi, S. A. 1971. Interrelationships between level of amino acids in plasma and tissues during starvation. Am. J. Physiol. 221: 829-838.

22. Nallathambi, S. A., A. M. Goorin, and S. A. Adibi. 1972. Hepatic and skeletal muscle transport of cycloleucine during starvation. Am. J. Physiol. 223: 13-19.

23. Munro, H. N., and A. Fleck. 1969. Analysis of tissue and body fluids for nitrogenous constituents. In Mammalian Protein Metabolism. H. N. Munro, editor. Academic Press, Inc., New York. III: 435-436.

24. Biggs, H. G., and J. M. Cooper. 1961. Modified folin methods for the measurement of urinary creatine and creatinine. Clin. Chem. 7: 655-664.

25. Young, V. R., S. D. Alexis, B. S. Baliga, H. N. Munro, and W. Muecke. 1972. Metabolism of administered 3-methylhistidine. Lack of muscle transfer ribonucleic acid charging and quantitative excretion as 3-methylhistidine and its $N$-acetyl derivative. J. Biol. Chem. 247: $3592-3600$.

26. Bilmazes, C., R. Uauy, L. N. Haverberg, H. N. Munro, and V. R. Young. 1977. Muscle protein breakdown rates in humans based on $N$-methylhistidine (3-methylhistidine) content of mixed proteins in skeletal muscle and urinary output of $\mathrm{N}$-methylhistidine. Metab. Clin. Exp. 27: $525-530$.

27. Umbreit, W. W., R. H. Burris, and J. F. Stauffer. 1964. Manometric Techniques. Burgess Publishing Co., Minneapolis, Minn. Fourth edition: 132-133.

28. Waalkes, T. P., and S. Udenfriend. 1957. A fluorometric method for the estimation of tyrosine in plasma and tissues. J. Lab. Clin. Med. 50: 733-736.

29. Adibi, S. A., J. A. Peterson, and B. A. Krzysik. 1975. Modulation of leucine transaminase activity by dietary means. Am. J. Physiol. 228: 432-435.

30. Lowry, O. H., N. J. Rosebrough, A. L. Farr, and R. J. Randall. 1951. Protein measurement with the Folin phenol reagent. J. Biol. Chem. 193: 265-275.

31. Rudiger, H. W., U. Langenbeck, and H. W. Goedde. 1972. A simplified method for the preparation of ${ }^{14} \mathrm{C}$-labeled branched-chain $\alpha$-oxo acids. Biochem. J. 126: 445-446.

32. Goodman, H. M. 1977. Site of action of insulin in promoting leucine utilization in adipose tissue. Am. J. Physiol. 233: E97-E103.

33. Snedecor, G. W. 1955. Statistical Methods. Iowa State 
University Press, Ames, Iowa. Fourth edition: 54-72.

34. Guroff, G., and S. Udenfriend. 1960. The uptake of tyrosine by isolated rat diaphragm. J. Biol. Chem. 235: 35183522 .

35. Li, J. B., and A. L. Goldberg. 1976. Effects of food deprivation on protein synthesis and degradation in rat skeletal muscles. Am. J. Physiol. 231: 441-448.

36. Asatoor, A. M., and M. D. Armstrong. 1967. 3-Methylhistidine, a component of actin. Biochem. Biophys. Res. Commun. 26: 168-174.

37. Johnson, P., C. I. Harris, and S. V. Perry. 1967. 3-Methy]histidine in actin and other muscle proteins. Biochem. J. 105: $361-370$.

38. Adibi, S. A., B. A. Krzysik, and A. L. Drash. 1977. Metabolism of intravenously administered dipeptides in rats: effects on amino acid pools, glucose concentration and insulin and glucagon secretion. Clin. Sci. Mol. Med. 52: 205-213.

39. Krzysik, B. A., and S. A. Adibi. 1979. Comparison of metabolism of glycine injected intravenously in free and dipeptide forms. Metab. Clin. Exp. 28: 1211-1217.

40. Adibi, S. A., T. A. Modesto, E. L. Morse, and P. M. Amin. 1973. Amino acid levels in plasma, liver, and skeletal muscle during protein deprivation. Am. J. Physiol. 225: $408-414$.

41. Clark, A. J., C. Yamada, and M. E. Swendseid. 1968. Effect of L-leucine on amino acid levels in plasma and tissue of normal and diabetic rats. Am. J. Physiol. 215: 13241328.

42. Halliday, D., and R. O. McKeran. 1975. Measurement of muscle protein synthetic rate from serial muscle biopsies and total body protein turnover in man by continuous intravenous infusion of $\mathrm{L}-\left[\alpha^{15} \mathrm{~N}\right]$ lysine. Clin. Sci. Mol. Med. 49: 581-590.

43. Haverberg, L. N., P. T. Omstedt, H. N. Munro, and V. R.
Young. 1975. N-methylhistidine content of mixed proteins in various rat tissues. Biochem. Biophys. Acta. 405: 67-71.

44. Rannels, D. E., E. E. McKee, and H. E. Morgan. 1977. Regulation of protein synthesis and degradation in heart and skeletal muscle. In Biochemical Actions of Hormones. G. Litwack, editor. Academic Press, Inc., New York. 4: 135-195.

45. Jefferson, L. S., J. B. Li, and S. R. Rannels. 1977. Regulation by insulin of amino acid release and protein turnover in the perfused rat hemicorpus. J. Biol. Chem. 252: 14761483.

46. Eaton, R. P. 1973. Effect of clofibrate on arginine-induced insulin and glucagon secretion. Metab. Clin. Exp. 22: 763-767.

47. Mortimore, G. E., and C. E. Mondon. 1970. Inhibition by insulin of valine turnover in liver. Evidence for a general control of proteolysis. J. Biol. Chem. 245: 23752383.

48. Sekowski, I., and P. Samuel. 1972. Clofibrate-induced acute muscular syndrome. Am. J. Cardiol. 30: 572-574.

49. Abourizk, N., B. A. Khalil, N. Bahuth, and A. K. Afifi. 1979. Clofibrate-induced muscular syndrome. J. Neurol. Sci. 42: 1-9.

50. Ontell, M., H. S. Paul, S. A. Adibi, and J. L. Martin. 1979. Involvement of transverse tubules in induced myotonia. J. Neuropathol. Exp. Neurol. 38: 596-605.

51. Adrian, R. H., and S. H. Bryant. 1974. On the repetitive discharge in myotonic muscle fibers. J. Physiol. (Lond.). 240: 505-515.

52. Schotland, D. 1970. An electron microscopic investigation of myotonic dystrophy. J. Neuropathol. Exp. Neurol. 29: 241-253.

53. Teravainen, H., A. Larsen, and M. Hillbom. 1977. Clofibrate-induced myopathy in the rat. Acta Neuropathol. 39: 135-138. 